\title{
The Status of women in the God of Small Things -A Feministic Approach
}

\author{
Dr. R. Anne Margaret \\ Senior Lecturer in English (Asso Professor in English) ABM Degree college, Ongole \\ Prakasam DT A.P. India
}

*Corresponding Author: Dr. R. Anne Margaret, Senior Lecturer in English (Asso Professor in English) ABM Degree college, Ongole, Prakasam DT A.P. India

\begin{abstract}
The sexual harassment of women depends on many things. The first and the most important source of power for the scheduled caste women are in their depressedness, the very nature of being scheduled caste. They belong to the original community which settled in India long before the influx of outsiders. That is why they are known as scheduled caste (untouchables), people who have been inhabitants of the soil from the beginning.

The aim of this article is to scrutinize and discuss in God of small things by Roy's perception of women's identity in Indian society during the contemporary period through some selected works. This unfolds through a re-visitation from a contemporary Indian women perspective. The ongoing study has first and foremost highlighted the impacts of industrialization on Indian Kara lite women's conditions. The second theme of this paper has consisted in showing how some of the fictional works authored by Arundhathy Roy has depicted and portrayed the social injustice prevailing in Indian Karalite during the period under study. Indeed, to achieve its objective, this research paper has lightly drawn on the feminist and new historicist theories while making an attempt to compare Roy's portrayal of women of contemporary Indian women.
\end{abstract}

Keywords: The image of women, portrayal of women, contemporary Indian women.

\section{INTRODUCTION}

Ammu is portrayed as a tragic figure, a woman struggling against her family, her mother hood and society. As Ranga Rao (The Hindu, Sep. 23rd 1997) puts it "In Ammu, the novelist has presented, with compassion, a woman, a feminist locked in a struggle with her family, its 'hidden morality' with society and tragically with herself. Her broken marriage, her unwantedness in her parental family has love for her children and her womanly desires lead her to her untimely death. These are not small things. These are terribly tyrannical forces against which she tries to rebel and thereby meets a tragic end.

Reena Kothari in her article "The Multiple Power Structure in Ayemenem" observes that Chacko, Mr. K.N. Pillai, Inspector Thomas Mathew, Baby Kochamma, Pappachi Mammachi etc., are responsible for the destruction of small things. Reena Kothari says: "Roy introduces the power structure in society and shows how the more powerful victimize the less powerful as there is gender oppression, oppression of lower caste, subjugation of children, police atrocity and the hypocrite Marxist Leader Mr.Pillai who too doesn't leave the opportunity to oppress anybody for personal gains. Roy's realistic sketch of her characters, be it Mammachi, Pappachi, Chacko or Baby Kochamma needs to be praised, for she scores well on his front. Multiple power structures remind us of our own society where such Chackos and Mammachis reside who exercise their power on the weak and less powerful" (136).

Nazma Malik in his article "The God of Small Things: A Study of English Influence on Indian Culture" comes close to Kothari's opinion by identifying the opposition of Indian and English dilemmas: "The Indian $V s$ the English Dilemma is illustrated throughout the novel. The God of small things breathes with the spirit of modern youth. It attacks several holy cows like the Communist establishment, family, religion etc" (167). 
Examining the popularity brought to Kerala by this novel Indira Nityanandam in the article "God's Own Country: Kerala in the God of Small Things" says: "Kerala remains a vibrant, throbbing presence". We can clearly see that Roy excels in evoking the local flavor and integrating it into the fabric of the novel. If Malgudi and Yoknapatawa are etched in the reader's mind, so is Ayememem which is probably today more globally recognizable than Kashmir. Kerala comes alive not merely in topographical details but breathes through the pages in the names, the endearing terms and dress of the characters. Pappachi, Mammachi, Mon, Mol, Chachen, Chetan, Kochamma, help root the novel in Malayalee society. Kerala is present not merely in the physical, external world but is an integral part of the novel in many more ways. The matriarchal family system is wrongly associated with the whole of Kerala though it is prevalent only among the Nair community and the erstwhile royal family of Travancore. Roy excels in evoking the local flavour and integrating it into the fabric of the novel" (179).

The critical perception of the novel in the light of Feminist centered consciousness brings in the issue of contested and explored Independence of women. Apart from the other thematic concerns like emphasizing the failure of Communism in Kerala and the atrocities perpetrated on 'Untouchables' in the Communist ruled Kerala, The God of Small Things conveys the Independence of women as a more significant theme to be noticed. The central character Ammu defies the laws of the society to realize her own world of freedom. Being the victim of gender discrimination in her family right from her childhood, she realizes that the social institutions hold an inevitable sway over the social maturation of women. Ammu's realization leads to serious silent resilience in every aspect of her life. In her attempts of exploring the realms of freedom she provides a space for Velutha, an untouchable, to experience equality. She understands that the social positions of Women in India and untouchables are almost similar. The pain and agony experienced in discrimination and the victimized positions bring Ammu and Velutha together. The status of freedom that the society has failed to provide to Velutha is facilitated by Ammu, who frames her own love laws. The attempts of Ammu in bringing Velutha to the world of love is understood to have disturbed the social hierarchical structure in the society. Dismantling of the social structure by woman receives the wrath of every institution in the society. 'The love laws' made by her to create a world of her freedom finally devour her life. But the attempts of Ammu signify and challenge the basic fallacies in the very formation of the society. The contestation and exploration of Ammu to create a world of her freedom is beyond the perception of classified notions of Feminism. One needs to go for an alternative critical concepts like 'Fourth World Feminism' that stands for the inclusion of women and untouchables of India to create the world of freedom.

The observation of Elain Showalter brings authenticity to this perception. She observes: "The voice we hear in God of Small Things is soft, heavy continuous a genuine accent of woman hood, one of the chorus of secret voices speaking out of our bones, dreadful and irritating but instantly recognizable".

It is in the light of these perceptions of Feminism the themes of the novels Wife, Interpreter of Maladies, Difficult Daughters, Raj and The God of Small Things should be analyzed. Wife and Interpreter of Maladies thematically stand for South Asian Feminism as they deal with the existential problems of immigrant women in the West. Difficult Daughters and Raj represent third world Feminism as they take us into the Pre and Post Colonial times of India. The changing social transmission of India is viewed from the Feminist perspective. The God of Small Things sets the tone for Fourth world Feminism as it has emphasized the theme of Dalit emancipation.

Feminist criticism was the direct product of the women's movement of 1916 . Feminism has become a vital aspect in literature in contemporary society and the female perspective, expressed through women's writing of all kinds is considered to be more than a valuable connective to an all male view of the universe. In exploring the question what is it to be woman lies the history of mankind: "History of mankind is the history of repeated injuries and usurpations on the part of man toward woman having indirect object the establishment of an absolute tyranny over her". (Declaration of Sentiments and Resolutions of The First Women's Rights Convention In America, Seneca Falls, 1848). It is perceived that the very subjection of women is consolidated by religion. The Holy Bible holds such observations and perceptions: "Wives submit yourselves to your 
husbands as to the Lord (The Holy Bible. Ephesians, 5: 22). This concept of women consolidated by Christianity affected their status for centuries. Gradually women lost the right to control their lives and as a result they were deprived not only of human rights but of humanity.

Literacy spread rapidly and women began to utilize the power of the pen. Betty Friedan, the mother of modern Feminism with the publication of Feminine Mystique (1963) initiated this new change. The new women's movement expanded into a commanding political force: "Women are an oppressed class. . . .We are exploited as sex objects, breeders, domestic servants, our prescribed behavior is enforced with threads of physical violence". (Lisa Turtle. Encyclopaedia of Feminism, 42).

Feminist writings were of crucial interest to the post-colonial discourse for two major reasons. First, both patriarchy and imperialism could be seen to exert different forms of domination over those subordinate to them. Because of this, it was important for the experiences of women under the patriarchal influence to come out to the forefront and expose the undue cruelty beheld on them by men. It was necessary for the women to oppose this male dominance over them. We observe that women continued to define the borders of the community, class and race. They tried to exert feminism in their works. Though the writers tried to depict the women as strong and focused in their vision to succeed in lives, they were, however, able to succeed in their lives only in the space allotted to them by the men. The protagonists in most of the contemporary novels belonged to the third world of feminism. These protagonists were exposed to the changed socio-cultural situation. Traveling in contemporary situation has facilitated the third world women for empowerment. The women, once they became mobile, automatically tended to make themselves dynamic and in turn became agents responsible for social change. 'Traveling' in its general understanding is the action executed by men. It is related to the acquirement of knowledge. Travelers are always men. Their journeys have always changed the discourse of the world. The literature evolved out of the travelers is also patriarchal in perception. The accounts of the travelers to India like Al Beruni, Fa hien, Huien Tsang etc have offered a very different version of Indian history which stood in negation with the official version of history. The history and literature created by the travelers though had its specific distinction, is not devoid of male perspective. To subvert this perception, third world women writers make their women protagonists to travel across the globe. Every journey initiates a new vision and creates a 'new self' in the lives of the women characters presented by third world women writers. It is this perception that almost decides the theme in Wife and The God of Small Things to the greater extent and in other novels to the lesser extent. The traveling enables women to overcome the obstacles like gender, class, race, caste etc.

\section{CONCLUSION}

Despite many international agreements affirming their human rights, women are still much more likely than men to be poor and illiterate. They usually have less access than men to medical care, property ownership, credit, training and employment. They are far less likely than men to be politically active and far more likely to be victims of domestic violence.

Women empowerment is also an essential element in national development. Since women constitute half of the population there can be no development unless the needs and interests of women are fully taken into account. As formal agency, the government of India wanted to improve the living conditions of women at different times. Here education played an important role for women empowerment. The activities of the missionary societies in the field of women's education have brought about tremendous changes in the society.

\section{REFERENCES}

[1] Roy, Arundhati. The God of Small Things. London: Flamingo, 1998.

[2] Adhikari, Madhumalathi. "Enclosure and Freedom: Arundhati Roy's God of Small things." Explorations Arundhati Roy's The God of small things. New Delhi: Nice Printing Press, 1999.

[3] Alieya. Perspective of an Indian Princess: Los Angeles: CAUSA, April 1, 2003.

[4] Amin, Amina. "Text and Counter Text Oppositional Discourse in The God of Small Things". Explorations Arundhati Roy's The God of Small Things. New Delhi: Nice Printing Press, 1999.

[5] Barche, G.D. "The God of Small Things: A study in Contradictions and Constraints". 
The Status of Women in the God of Small Things -A Feministic Approach

Explorations Arundhati Roy's The God of Small Things._New Delhi: Nice Printing Press, 1999.

[6] Beau Noir, Simonde. The Second Sex. Great Britain: Vintage, 1997.
[7] Bergner, Gwen. "Who is That Masked Women? Or the Role of Gender in Fanon's Black Skin, White Masks. PMLA, 110, Jan. 1995.

[8] Betty, Frieday. The Feminine Mystique. New York: Dell, 1963.

Citation: Dr. R. Anne, Margaret. "The Status of Women in the God of Small Things -A Feministic Approach." International Journal of Research In Humanities and Social Studies, vol 4, no. 4, 2017, pp. 1316.

Copyright: (C) 2017 Dr. R., Anne Margaret. This is an open-access article distributed under the terms of the Creative Commons Attribution License, which permits unrestricted use, distribution, and reproduction in any medium, provided the original author and source are credited. 